\title{
Macroeconomic Stability, Financial Stability, and Monetary Policy Rulles*
}

\author{
Pierre-Richard AgÉnor
}

Luiz A. Pereira da Silva

$C$ Pierre-Richard Agénor is Hallsworth Professor of International

Macroeconomics and Development Economics at the University of Manchester. He is also co-Director of the Centre for Growth and Business Cycle Research, and International Research Fellow at the Kiel Institute of the World Economy. He is Senior Fellow Ferdi.

C Luiz A. Pereira da Silva is Deputy Governor at Central Bank of Brazil.

\section{Abstract}

This paper reviews arguments for and against attributing explicitly a financial stability objective to monetary policy. The discussion is conducted from the perspective of middle-income countries (MICs), where bank credit plays a critical role both on the supply and demand sides. It also discusses, assuming that a more proactive role is desirable, what monetary policy should react to, to what extent it should be combined with macroprudential regulation (and possibly capital controls), and whether existing models provide adequate benchmarks for studying how these policies interact. The analysis suggests that, on balance, there may be a good case for monetary policy in MICs to go beyond its conventional mandate and address the time dimension of systemic risk -if only during a transitory period, as more is learnt about the implementation and performance of the new macroprudential rules that are currently being discussed. . . . . . . 


\title{
Macroeconomic Stability, Financial Stability, and Monetary Policy Rules
}

\author{
Pierre-Richard Agénor* and Luiz A. Pereira da Silva** \\ First complete draft: August 12, 2011 \\ This version: September 24, 2011
}

\begin{abstract}
This paper reviews arguments for and against attributing explicitly a financial stability objective to monetary policy. The discussion is conducted from the perspective of middle-income countries (MICs), where bank credit plays a critical role both on the supply and demand sides. It also discusses, assuming that a more proactive role is desirable, what monetary policy should react to, to what extent it should be combined with macroprudential regulation (and possibly capital controls), and whether existing models provide adequate benchmarks for studying how these policies interact. The analysis suggests that, on balance, there may be a good case for monetary policy in MICs to go beyond its conventional mandate and address the time dimension of systemic risk-if only during a transitory period, as more is learnt about the implementation and performance of the new macroprudential rules that are currently being discussed. There are robust arguments in favor of monetary policy reacting in a state contingent fashion to a (private sector) credit growth gap measure, not only because of financial stability considerations but also because of the high degree of uncertainty regarding real time estimates of the output gap in MICs. Nevertheless, monetary policy is not a substitute to macroprudential regulation - because monetary policy cannot, in any event, address the cross-section dimension of systemic risk, and because MICs often face circumstances (e.g., sudden floods) where it could have undesirable side effects if used as an exclusive policy instrument.
\end{abstract}

*Hallsworth Professor of International Macroeconomics and Development Economics, University of Manchester, co-Director, Centre for Growth and Business Cycle Research, and Senior Fellow, FERDI (Fondation pour les études et recherches sur le développement international); **Deputy Governor, Central Bank of Brazil. This paper dwells in part on some of our previous papers, including joint work with Koray Alper (Central Bank of Turkey). Financial support by FERDI is gratefully acknowledged. We are grateful to Koray Alper, Karim El Aynaoui, and participants at the Inter-American Development Seminar for Central Banks and Finance Ministries (Washington DC, September 21-23, 2011) for helpful discussions and comments. However, we bear sole responsibility for the views expressed in this paper. 


\section{INTRODUCTION}

The global financial crisis has led to both a reassessment of financial regulatory systems worldwide — even in countries whose financial systems were largely shielded from its most direct impact—and renewed calls for central banks to consider more explicitly and more systematically financial stability considerations in setting monetary policy. On the regulatory side, a number of proposals aimed at strengthening the financial system and at encouraging more prudent lending behavior in upturns have been put forward. In particular, it has been argued that by raising capital requirements in a contra-cyclical way, regulators could help to choke off asset price bubbles—such as the one that developed in the US housing market—before a crisis develops. ${ }^{1}$ Along these lines, and after months of internal debate, on September 12, 2010 the Basel Committee on Banking Supervision (BCBS) released a new capital framework which not only strengthens the definition of capital but also recommends the implementation of both a capital conservation buffer and a countercyclical capital buffer, with the latter ranging from 0 to 2.5 percent of risk-weighted assets. According to the proposed rule, bank capital should be adjusted in response to excess growth in credit to the private sector, which is viewed as a reliable indicator of systemic risk.

On the monetary policy side, it has been argued that central banks should consider more systematically potential tradeoffs between the objectives of macroeconomic stability and financial stability. ${ }^{2}$ One reason for that is the growing concern among academics and policy-makers that the achievement of price stability may have been associated with an increased risk of financial instability. Indeed, it has been argued that financial imbalances may build up even in an environment of stable prices; low and stable rates of inflation may even foster asset price

\footnotetext{
${ }^{1}$ The Turner Review (see Financial Services Authority (2009)) for instance favors countercyclical capital requirements, and so do Brunnermeier et al. (2009), who proposed to adjust capital adequacy requirements over the cycle by two multiples - the first related to above-average growth of credit expansion and leverage, the second related to the mismatch in the maturity of assets and liabilities. Many of these proposals aim to mitigate the alleged procyclical effects of Basel II capital standards, which were more focused on the microprudential aspects of financial regulation; see Agénor and Pereira da Silva (2009, 2010) for a developingcountry perspective.

${ }^{2}$ The debate actually predates the global financial crisis and initially focused on the extent to which monetary policy should respond to (or "lean against") perceived misalignments in asset prices, such as real estate and equity prices, as opposed to “cleaning up after.” In this vein, Cecchetti et al. (2000) and Kontonikas and Ioannidis (2005) found that overall economic volatility can indeed be reduced with a (mild) reaction of interest rates to asset price misalignments from fundamentals. See Wadhwani (2008) for a review.
} 
bubbles, due for instance to excessively optimistic expectations about future economic prospects or to increased incentives to take on more risk. Thus, price stability may not be a sufficient condition for financial stability. At the same time, however, several observers have argued that trying to stabilize asset prices per se is problematic for a number of reasons-in particular because it is almost impossible to know for sure whether a given change in asset values results from changes in underlying fundamentals, nonfundamental factors, or both. Some observers have argued that, instead of getting into the tricky issue of deciding to what extent asset price changes reflect changes in the economy's fundamentals, central banks should focus on the implications of asset price movements for credit growth and aggregate demand, and thus inflationary pressures.

This paper focuses on the second issue- the extent to which monetary policy should be concerned explicitly with financial stability objectives and, if so, to what financial indicators it should be made responsive to. We do so in the context where macroprudential regulation is also a component of the policy framework aimed at preventing disruptive and costly financial crises. ${ }^{3}$ Specifically, in addition to, or instead of, a cyclical component to prudential regulation, should policymakers make monetary policy rules more responsive to (some measure of) financial (in)stability, such as asset prices or credit growth directly? To what extent should regulatory rules and monetary policy be combined to ensure both macroeconomic and financial stability? Put differently, are these policies complementary or substitutes?

To conduct this analysis, and in contrast to much of the existing literature, we focus on middle-income countries (MICs) only. We do so for several reasons. First, financial markets in many of these countries remain underdeveloped. In most MICs, commercial banks continue to dominate the financial system. Equity issues remain limited, despite recent progress in deepening local capital markets and changes in the ownership structure of firms. Capital markets remain thin; local currency bond markets are still in their infant stages in

${ }^{3}$ Our discussion of macroprudential policy is thus focused on the extent to which it interacts with monetary policy. For a more general discussion, including coordination issues between these two policies, see Committee on the Global Financial System (2010), Financial Stability Board (2011), Galati and Moessner (2011), and International Monetary Fund (2011b). See Schou-Zibell et al. (2010) for a practical application of a macroprudential approach to assessing financial stability. Note also that we abstract from the potential from the potentially important role of countercyclical fiscal policy in dampening financial cycles. 
many economies and do not represent significant alternatives to bank lending. ${ }^{4}$ In some countries, a narrow domestic investor base leaves the market susceptible to high volatility. At the same time, although privatization and cross-border acquisitions have improved in recent years the degree of banking sophistication in many countries, their financial systems continue to lag behind developments in industrial markets. In particular, and despite some exceptions, the expansion of nonbank financial intermediaries (hedge funds, commodities funds, private equity groups, and money market funds), the shift toward the "originate and distribute” model of banking, and the development of opaque, off-balance sheet instruments, have not reached the same importance as they have in advanced economies. ${ }^{5}$

Second, and related to the lack of financial diversification, bank credit has an important impact on the supply-side of the economy. Firms borrow short-term to finance their working capital needs (such as labor inputs and raw materials) prior to the sale of output. But while an increase in the cost of loans for consumption or investment (induced by a contraction in monetary policy) tends to reduce both aggregate demand and inflationary pressures, an increase in the cost of working capital loans affects output and inflation in opposite directions. This makes the transmission of monetary policy shocks to prices highly uncertain.

Third, the financial system in MICs is often highly vulnerable to small domestic or external disturbances - even more so now to global financial cycles, as a result of increased international financial integration. Abrupt reversals in short-term capital movements tend to exacerbate financial volatility-particularly in countries with relatively fragile financial

\footnotetext{
${ }^{4}$ According to data for 2009 in the IMF’s Global Financial Stability Report (Appendix Table 1, April 2011), as a share of GDP, stock market capitalization amounted to 52.7 percent, private debt securities for 143.6 percent, and bank assets for 267.9 percent for the Euro Area, and 106.8 percent, 157.0 percent, and 100.3 percent, respectively, for the United States. The corresponding figures for Latin America for instance were 54.9, 20.9, and 70.4 percent, and for Asia 68.7, 18.9, and 155.4 percent, respectively.

${ }^{5}$ See Pozsar et al. (2010). Alternatives to conventional bank finance in industrial countries include invoice factoring or discounting (where a business borrows money against its invoices), asset-based financing (where money is borrowed against assets such as plant or machinery), peer-to-peer and consumer-to-business lending (in which individuals agree to lend money to each other or to businesses through an online money exchange). New lending models also involve providing cash advances to businesses (e.g., restaurants and hotels) that derive much of their income through credit card sales. However, most of these new lending models haven't reached a critical mass of borrowers to be considered serious alternatives to bank finance.
} 
systems, weak regulatory and supervision structures, and policy regimes that lack flexibility. ${ }^{6}$ A number of studies have indeed documented a positive relation between the increasing international capital flows due to greater integration with world financial markets and the vulnerability to sudden reversals in capital flows. For instance, Broto et al. (2011) found that since 2000 global factors have become increasingly significant relative to country-specific drivers in determining the volatility of capital inflows into several MICs, whereas Dufrénot et al. (2011) found that stress indicators in US financial markets in the aftermath of the subprime crisis caused abrupt changes in stock market volatility in several Latin American countries. Forbes and Warnock (2011) also found that global factors play an important role in explaining "waves" of international capital flows. The more open and integrated a country is to global financial markets, the deeper are the channels through which reversals in capital flows will impact both the real economy and the financial system —and the more critical the policy response becomes to ensure macroeconomic and financial stability.

Fourth, MICs have suffered many costly crises over the past decades, with large drops in output, persistent credit crunches, and sharp increases in unemployment and poverty. Moreover, some of these effects tend to be highly asymmetric (see Agénor (2002)). Although the exact trigger to these crises can be almost any event (including political turmoil, a real estate crash, a sharp decline in the terms of trade, or contagion from other economies), making it hard to predict their exact timing, they are often preceded by sustained imbalances. Thus, any measure (related or not to macroprudential policy or monetary management) that can help to identify sources of weaknesses, prevent these imbalances from emerging, and minimize the chances of a crisis occurring may have large welfare benefits.

The remainder of this paper proceeds as follows. Section II considers the case against using monetary policy to react directly to financial instability; from our perspective, this is tantamount to arguing that macroprudential tools, possibly supplemented by capital controls, are enough or more appropriate to mitigate systemic risk. Section III considers the case for a more proactive monetary policy in response to perceived risks to financial stability, above and

\footnotetext{
${ }^{6}$ See Park and Lee (2011) for evidence of increased financial integration in Asia during the past two decades and Agénor (2011) for a more thorough review of the evidence on, and the challenges posed by,
} 
beyond the conventional objectives of price and output stability. Section IV discusses what monetary policy should react to, assuming indeed that a more proactive role is desirable. Section V addresses the issue of whether monetary policy should be combined with macroprudential regulation (and possibly capital controls) using a rules-based approach. Section VI examines to what extent existing models for monetary policy analysis in an MIC context are up to the task, when it comes to studying and calibrating these rules. The last section offers some concluding remarks.

\section{THE CASE AGAINST A MORE PROACTIVE ROLE OF MONETARY POLICY}

There are a number of arguments that militate against using monetary policy to address directly financial stability concerns.

The first is the so-called Tinbergen's principle, which states that to attain a given number of independent policy objectives, there must be at least an equal number of instruments. ${ }^{7}$ For the issue at hand, with macroeconomic stability and financial stability being the two objectives, it means that two separate tools are needed — the policy interest rate and a macroprudential tool. Put differently, policymakers necessarily need a tool other than the interest rate—-particularly if there are potential tradeoffs between policy objectives. ${ }^{8}$ With an additional instrument, and in a deterministic environment, the central bank can achieve

\footnotetext{
international financial integration.

${ }^{7}$ Tinbergen's principle is concerned with the existence and location of a solution to the system; it does not assert that any given set of policy responses will, in fact, lead to that solution. To assert this, it is necessary to investigate the stability properties of a dynamic system.

${ }^{8}$ An example of tradeoffs between monetary policy and macroprudential policy can be derived from the analysis in Agénor, Alper, and Pereira (2009), in a model where the impact of the "bank capital channel” on loan rates takes two forms: a cost effect (associated with the fact that issuing equity or debt for regulatory purposes is costly) and a monitoring incentive effect (due to the fact that more capital improves banks' monitoring incentives and leads to an increase in borrowers' repayment probability). Consider a negative supply shock for instance, which lowers output (thereby raising the risk of default) and raises prices. If the central bank raises the policy rate (to fend off inflationary pressures) and at the same time increases the minimum capital adequacy ratio (to promote financial stability), the net effect on the loan rate may be ambiguous. Indeed, the direct effect of a higher policy rate (the marginal cost of liquidity for lenders) is to raise the loan rate-and so does the increase in the cost of accumulating capital, which must rise to induce households to hold the additional equity or debt. However, at the same time higher bank capital leads to a higher repayment probability (through the monitoring incentive effect), which tends to reduce the loan rate.
} 
exactly, and continuously (through dynamic rules) its targets; the two instruments are necessarily complements. From that perspective, the issue of whether monetary policy should respond to financial stability concerns is simply not relevant; it must be combined with macroprudential policy, regardless. This is, implicitly at least, the argument put forward by Svensson (2010). In practice, however, central banks operate in a stochastic world and aim to minimize deviations from their targets, rather than achieving them exactly and continuously; and because each instrument, manipulated independently, may affect both targets in the same direction (thereby reducing volatility in both cases), they may therefore be substitutes. This issue is discussed further in Section IV.

The second argument is that monetary policy, precisely when it is successful at maintaining low and stable prices, may itself induce boom-bust cycles in asset prices; low interest rates may encourage increased risk taking, excessive leverage, and promote a "search for yield." ${ }^{9}$ If so then there may be a tradeoff between macroeconomic and financial stability. This argument has been used in part to highlight a contributing factor to the recent financial crisis: the low interest rates and low inflation that have been associated with the Great Moderation created in advanced economies an environment encouraging increased risktaking - with a switch from a lower yield on safe assets into higher-yielding risky assets, driving their prices up in the process—and more leveraging, which subsequently led to asset price bubbles. However, it has also been argued that tradeoffs of this nature between (future) financial (in)stability and present macroeconomic stability should not be addressed through tighter monetary policy, but rather by more targeted macroprudential measures.

The possibility that loose monetary policy might have played a part in generating the preconditions for the global financial crisis is illustrated by comparing policy rates with the policy settings generated by a benchmark Taylor rule. Figure 1 shows the difference between the actual policy rate and benchmark estimates of the appropriate policy rate derived from a Taylor rule for the United States, the euro area and the United Kingdom. The figure shows clearly that the Federal Funds rate was very low relative to the Taylor rule from 2001 to 2005

\footnotetext{
${ }^{9}$ See Rajan (2005) for the "search for yield” argument. Bean et al. (2010) provide a brief review of the alternative channels through which loose monetary policy may encourage increased risk-taking.
} 
in the aftermath of the collapse of the dot-com bubble. Although less significant, this was also the case in the Euro area. ${ }^{10}$ In both cases, the accommodative policy stance may indeed have had a strong impact on asset prices and credit growth. ${ }^{11}$ However, this does not mean that monetary policy should respond directly to these variables: if increases in asset prices and credit growth are expected to lead to an expansion in aggregate demand (through wealth and direct effects on private spending), a policy that reacts to the output gap and (expected) inflation would naturally lead to an endogenous policy response. There would be no need to respond directly to these variables. Put differently, excessive asset prices and credit growth matter only to the extent that they affect the future path of output and inflation.

The third argument is that, to the extent that it affects all lending activities (regardless of whether they represent a risk to stability), the policy interest rate is too blunt an instrument to be useful to address financial stability concerns, which often have a sectoral dimensionsuch as, for instance, overheating of the housing market. From that perspective, imposing a cost on the entire economy is not warranted — even though there is evidence to suggest a high correlation between credit growth, which depends on the cost of borrowing and thus the policy rate, and house price inflation (see Claessens et al. (2010)). Because the effect of higher policy rates on bank risk taking may depend on each institution’s initial capital position, the net aggregate effect may be limited. Banks with a low capital base (or less to lose) for instance may try to "gamble" by expanding the asset side of their balance sheets, by lending to increasingly riskier borrowers, whereas highly capitalized banks may choose to diversify their portfolios toward less risky assets. In addition, trying to “prick” a developing housing price bubble through a (possibly very large) economy-wide increase in the cost of borrowing could have an immediate adverse effect on the supply side, given the importance (as indicated earlier) of bank credit in financing working capital needs. In turn, this may increase macroeconomic volatility. In such conditions, sectoral prudential tools (such as

\footnotetext{
${ }^{10}$ The low interest rates in the Euro Area may have been themselves the consequence of the low interest rates in the United States, as the European Central Bank tried to avoid a real appreciation induced by high interest rate differentials.

${ }^{11}$ In a broader study of OECD countries, Ahrend (2010) found that, during periods when short-term interest rates have been persistently and significantly below what Taylor rules would prescribe, monetary policy has had a significant effect on increases in asset prices, especially housing prices. See, however, Bernanke
} 
changes in loan-to-value ratios, debt-to-income ratios, countercyclical capital requirements on real estate lenders, and so on) may be more appropriate to prevent risk concentration. ${ }^{12}$ This, of course, assumes that the sector(s) at the source of financial vulnerabilities can be identified with sufficient confidence.

Figure 1

Industrial Countries: Deviations of Policy Rates from Taylor Rules, 2000-09

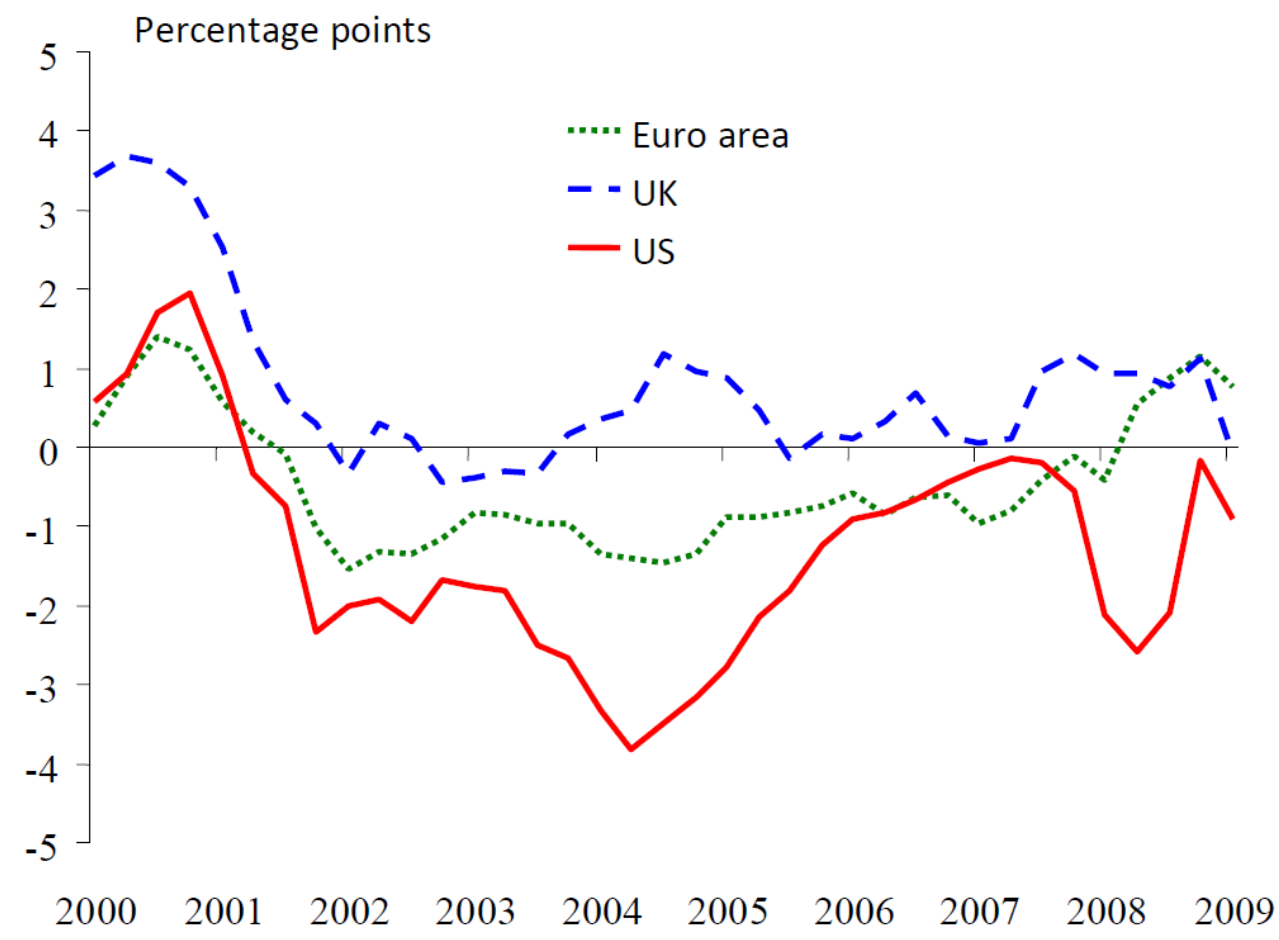

Source: Bean et al. (2010).

The fourth argument goes even further-depending on the nature of shocks, monetary policy may need to be conducted with caution, because of potentially undesirable side effects. This is what occurs when a country is confronted with a sudden flood of private capital, that is, large inflows induced by changes in external market conditions (Agénor, Alper, and Pereira da Silva (2011b)). Indeed, sudden floods have been on numerous occasions a source

(2010) for an alternative view in the case of the United States. Svensson (2010) also rejects the view that the financial crisis was caused by an excessively accommodative monetary policy stance.

${ }^{12}$ See Crowe et al. (2011) for a discussion of policy options for dealing with real estate booms. However, it is important to recognize at the same time that targeted tools, although they may be less costly than an economy-wide increase in interest rates, could be easier to circumvent then broader measures. 
of macroeconomic instability in many MICs, as a result of rapid credit and monetary expansion (due to the difficulty and cost of pursuing sterilization policies), inflationary pressures, real exchange rate appreciation, and widening current account deficits. In particular, the surge in capital flows to MICs since 2008 — caused in part by the post-crisis global excess liquidity generated by the expansionary monetary policies of advanced reserve currency-issuing countries—-has induced booms in credit and equity markets, real appreciation, and inflationary pressures in many MICs and raised concerns about asset price bubbles and financial fragility in these countries. ${ }^{13}$ Some of these effects are illustrated in Figure 2, which shows the link between capital inflows and the growth rates of real credit and equity prices for a group of Asian and Latin American countries, and in Figure 3, which also shows the link between capital inflows and real credit growth in Turkey.

At the same time, the scope for responding to the risk of macroeconomic and financial instability through monetary policy is limited because higher domestic interest rates vis-à-vis interest rates in advanced economies may simply exacerbate the flood of private capital. Put differently, monetary policy loses its effectiveness and other instruments (macroprudential tools, capital controls) must be used to manage capital flows and mitigate their destabilizing effects on the domestic economy.

A fifth and related argument is that strengthening macroprudential rules, using both “old” instruments (such as liquidity or leverage ratios, loan-to-value and debt-to-income ratios, and so on) and "new” tools, such as countercyclical capital buffers linked to a measure of excessive credit growth (as envisaged under Basel III) and dynamic provisioning, offers a better alternative to monetary policy. In fact, both types of instruments have been used in MICs for years. The Central Bank of Brazil introduced a capital charge in 2000, through a mechanism that links the deviation of credit growth relative to GDP growth. More recently,

\footnotetext{
${ }^{13}$ There is significant evidence documenting these effects. Jongwanich (2010) for instance, in a study of a group of Asian countries over the period 2000-09, found that capital inflows lead to a significant real appreciation. Using a broader sample of countries over the period 1970-2007, Furceri et al. (2011) found that in the two years following the beginning of a capital inflow shock, the credit-to-GDP ratio increases by about 2 percentage points. The study also found that the short-term effect of capital inflow shocks on domestic credit depends on countries' macroeconomic policy stances. In particular, it is lower in countries with a higher degree of exchange rate flexibility.
} 
dynamic provisioning rules have been imposed in several Latin American countries (see Wezel (2010)). In addition to reducing balance sheet vulnerabilities, these instruments have helped to reduce risk taking and strengthen the financial sector (dynamic provisions), explaining in part why MICs were able to weather the recent global financial crisis with limited strain. ${ }^{14}$ As documented by Montoro and Moreno (2011) for instance, reserve requirements were used in Latin America in a countercyclical fashion to smooth the expansion phase of the cycle and to tighten monetary conditions without attracting capital inflows. During the global financial crisis, reserve requirements were lowered, in order to inject liquidity rapidly in local and foreign currency and restore market activity affected by sudden reversals in capital inflows. ${ }^{15}$ In another study on Latin America, Terrier et al. (2011) provided a broader review of microprudential policy tools used or available to policymakers in the region to mitigate the procyclical effects of financial cycles. ${ }^{16}$ They conclude that, although mainly microprudential in nature, when appropriately calibrated and used in combination over the financial cycle these tools may prove effective for macroprudential purposes and could contribute significantly to addressing systemic risk.

\footnotetext{
${ }^{14}$ In some countries, low direct exposure of financial institutions to complex derivatives and subprimerelated structured credit products may have been due not only to strict regulations but also to relatively high returns to domestic banking operations.

${ }^{15}$ Several countries in the region (namely, Brazil and Colombia) also resorted to capital controls.

${ }^{16}$ The tools examined include capital requirements, dynamic provisioning, and leverage ratios; liquidity requirements; debt-to-income and loan-to-value ratios; reserve requirements on bank liabilities (deposits and nondeposits); instruments to manage and limit systemic foreign exchange risk; and reserve requirements or taxes on capital inflows.
} 
Figure 2

Asia and Latin America: Capital Inflows, Real Credit, and Real Equity Prices, 1996-2010
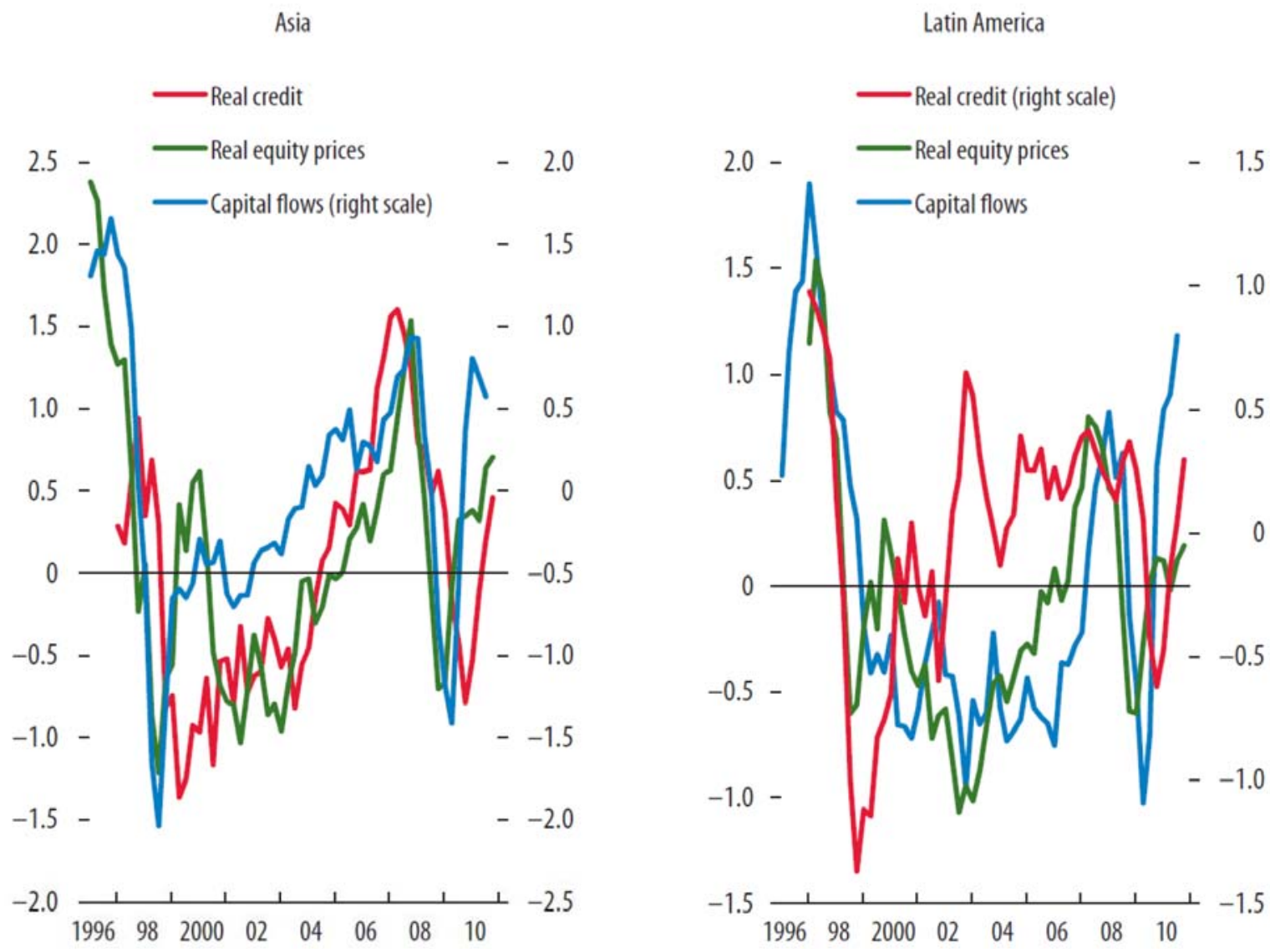

Source: International Monetary Fund, Global Financial Stability Report (April 2011).

A sixth argument is that if financial imbalances are related to excessive credit growth, and if credit growth is fueled by capital inflows (as is often the case in MICs), then a more effective policy could be to complement macroprudential tools —at least temporarily—with capital controls. The evidence regarding the effectiveness of capital controls is, at best, mixed. In the 1990s, capital controls were only temporarily able to drive a wedge between foreign and domestic interest rates and to reduce pressures on the exchange rate in countries like Brazil, Chile, Colombia, Malaysia, and Thailand (Ariyoshi et al. (2000)). More recent reviews, which include the Committee on the Global Financial System (2010), Agénor (2011), Habermeier et al. (2011), and International Monetary Fund (2011a), reached similar conclusions: capital controls appear to have had little effect on overall capital flows, although 
they may have had some success in altering the composition of these flows. ${ }^{17}$ In most cases, controls have not been successful at mitigating currency appreciation. Specific econometric estimates on the effectiveness of capital controls covering four MICs during the 2000s (Brazil, Columbia, Korea, and Thailand) confirm that controls have met with mixed success. It also appears that the effectiveness of any given measure decays over time. ${ }^{18}$ Nevertheless, temporary effectiveness may well be all that policymakers need, when faced with sudden floods and neither monetary policy nor macroprudential policy can respond quickly.

A seventh argument is that if the central bank lacks credibility, adding a financial stability objective to monetary policy may confuse markets, weaken perceived commitment to price stability, and destabilize expectations - thereby making it more difficult to maintain low inflation. In such conditions, there may be a stabilization cost associated with using monetary policy in a proactive manner. Suppose for instance that policymakers are faced with a negative demand shock that lowers both output and inflation. In an inflation targeting regime, the correct policy response is to lower the policy rate; there is no tradeoff between macroeconomic objectives. But if the central bank is concerned with systemic risk (perhaps because of the belief that low interest rates may promote risk taking motivated by a "search for yield”, as discussed earlier), a conflict between macroeconomic and financial stability objectives emerges: keeping interest rates high means that the risk of deflation must be accepted.

\footnotetext{
${ }^{17}$ A recent study for instance is Gochoco-Bautista e al. (2010), who examined the effects of capital control measures on the volume and composition of capital flows using panel regressions for 9 Asian countries (China, Hong Kong, India, Indonesia, Korea, Malaysia, the Philippines, Singapore, and Thailand) over the period 1995-2005. They found that capital controls did affect the composition of capital flows. However, there is also evidence that limits on capital inflows hampered the development of financial markets in the region; see McCauley (2008). Another study is Jongwanich et al. (2011), who examined not only the effects of restrictions on the volume of capital flows (aggregate, inflows, and outflows), but also on particular asset categories of capital flows (portfolio, direct, and other investment flows). Restrictions in Thailand had no significant effect on inflows but were especially effective for outflows, particularly foreign direct investment. In Malaysia, capital relaxation had a significant impact on inward foreign direct investment and portfolio inflows. Changes in capital account restrictions did not have a significant impact on the real exchange rate in both Malaysia and Thailand.
} 
Figure 3

Turkey: Capital Inflows and Real Credit Growth, 2005-11

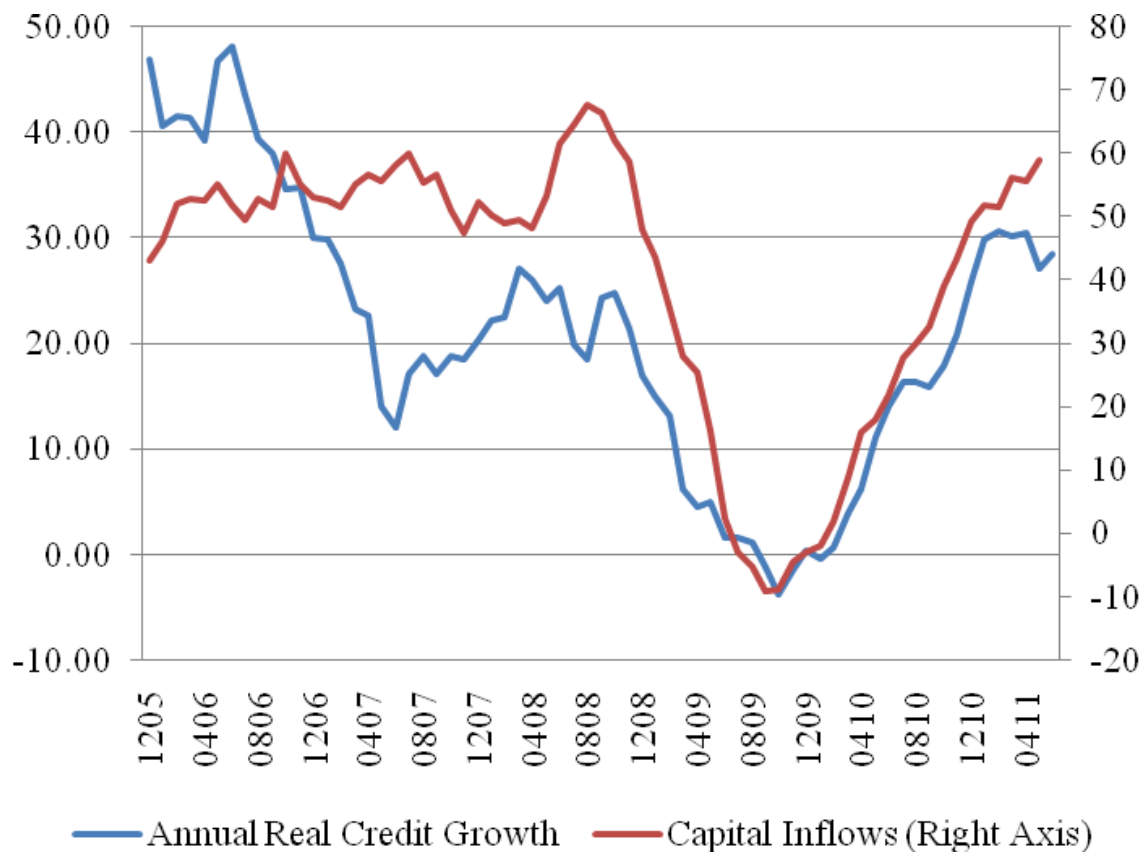

Note: Capital inflows are the sum of for'eign direct investment, portfolio flows, and other Investment, and are measured in billions of US dollars.

Source: Central Bank of Turkey.

In such conditions, some observers have proposed, as a policy response, to lengthen the horizon for achieving the inflation target. This is the same response typically advocated in the case of a (persistent) supply shock, which entails a tradeoff between output and inflation. However, concerns about systemic risk, which includes both time and cross-sectional dimensions, may be difficult to convey to agents, unlike other worries (e.g., the inflationary impact of an oil price shock). Indeed, even though substantial progress has been achieved in recent years, there is still no consensus (or at least much more controversy) on defining "financial stability" and how to measure it in its various dimensions. If so, lengthening the target horizon may have adverse effects on inflation expectations and central bank credibility.

\footnotetext{
${ }^{18}$ Habermeier et al. (2011) also found that prudential measures appear to have had more success in stemming credit growth and addressing financial stability concerns than capital controls. However, we do not share this view, as discussed later in the context of the pre-crisis experience in Latin America.
} 
Similar reasoning suggests that allowing instead a wider fluctuation band for the inflation target could have equally adverse effects on credibility.

\section{THE CASE FOR A MORE PROACTIVE MONETARY POLICY}

There are also a number of arguments that militate in favor of making monetary policy more directly responsive to a financial stability objective.

The first argument is that there is no evidence that (loose) monetary policy has been a systematic cause of boom-bust cycles in credit and asset prices in MICs. To begin with, very few MICs maintained policy interest rates at low levels during extended times, so identifying periods during which the correlation between low interest rates and risk taking can be studied is difficult. A more substantive reason for the lack of evidence on this correlation is that banks in these countries have maintained for years capital ratios well above those required by international standards, as documented by Agénor and Pereira da Silva (2010) and Fonseca, González, and Pereira da Silva (2010). In a sense, having more "skin in the game” reduced incentives to gamble and may have prevented a weakening of balance sheets through imprudent lending practices. A third reason is the fact that in many countries sectoral (micro) prudential tools were actively used to mitigate excessive risk taking. In addition, with noncompetitive credit markets (a common characteristic of banking in MICs), low policy rates may mean higher bank spreads, higher profits, and possibly less risk. Put differently, if there is no evidence that monetary policy has potentially perverse side effects on financial stability, there should be less concern in attributing a financial stability target to it. In general, excessive risk taking has to do with procyclicality, which is itself driven by optimistic expectations and the tendency by lenders to relax lending standards and underprice risks in good times (especially during episodes of sudden floods). It is indeed well documented that bank intermediation is highly procyclical in MICs (see Claessens et al. (2010) and Calderón and Fuentes (2011)). In such conditions, monetary policy—possibly in combination with some specific macroprudential tools_-could help to mitigate procyclicality and thereby 
address the time dimension of systemic risk, through its effect on the economy-wide cost of borrowing.

A second and related argument is that while monetary policy should not be used to "prick" stock market bubbles, it could be quite effective at deflating debt-financed bubbles, especially if they are credit-financed-a very likely scenario in MICs. ${ }^{19}$ By inducing a direct increase in the cost of borrowing, monetary policy may be more powerful than macroprudential policy in these circumstances.

A third argument is that it is not obvious that macroprudential policy was all that successful prior to the crisis. Indeed, in several MICs macroprudential measures did not prevent rapid credit growth in the lead-up to the crisis. Figure 4 for instance shows that credit was increasing at alarmingly high rates in Latin America prior to 2007. More specifically, as illustrated in Figure 5, prior to the onset of the global financial crisis credit growth was accelerating in Brazil, Colombia, and Peru (as well as in countries like Venezuela). A good question is whether these countries would have faced a crisis, even without turmoil in advanced economies; if history is any guide, the likelihood appears to be quite high. But rather than an argument in favor of greater reliance on monetary policy, this evidence may be construed as a call for using macroprudential tools more aggressively or for adding new tools to the arsenal of policymakers. Indeed, Colombia (between July 2007 and July 2008) and Peru (in November 2008) both introduced dynamic loan provisioning systems in the aftermath of the global financial crisis. At the same time, the less effective macroprudential tools are, the greater the potential role of monetary policy to contribute to maintaining financial stability.

\footnotetext{
${ }^{19}$ Blinder (2010) and Mishkin (2011) have both emphasized the distinction between credit-fueled bubbles (such as house price bubbles) and equity-type bubbles (in which credit plays only a minor role) in their analysis of post-crisis monetary policy. However, they are fairly agnostic as to whether the central bank should try to limit credit-based bubbles through regulatory instruments or interest rates.
} 
Figure 4

Real Credit Growth to the Private sector, 2002-10

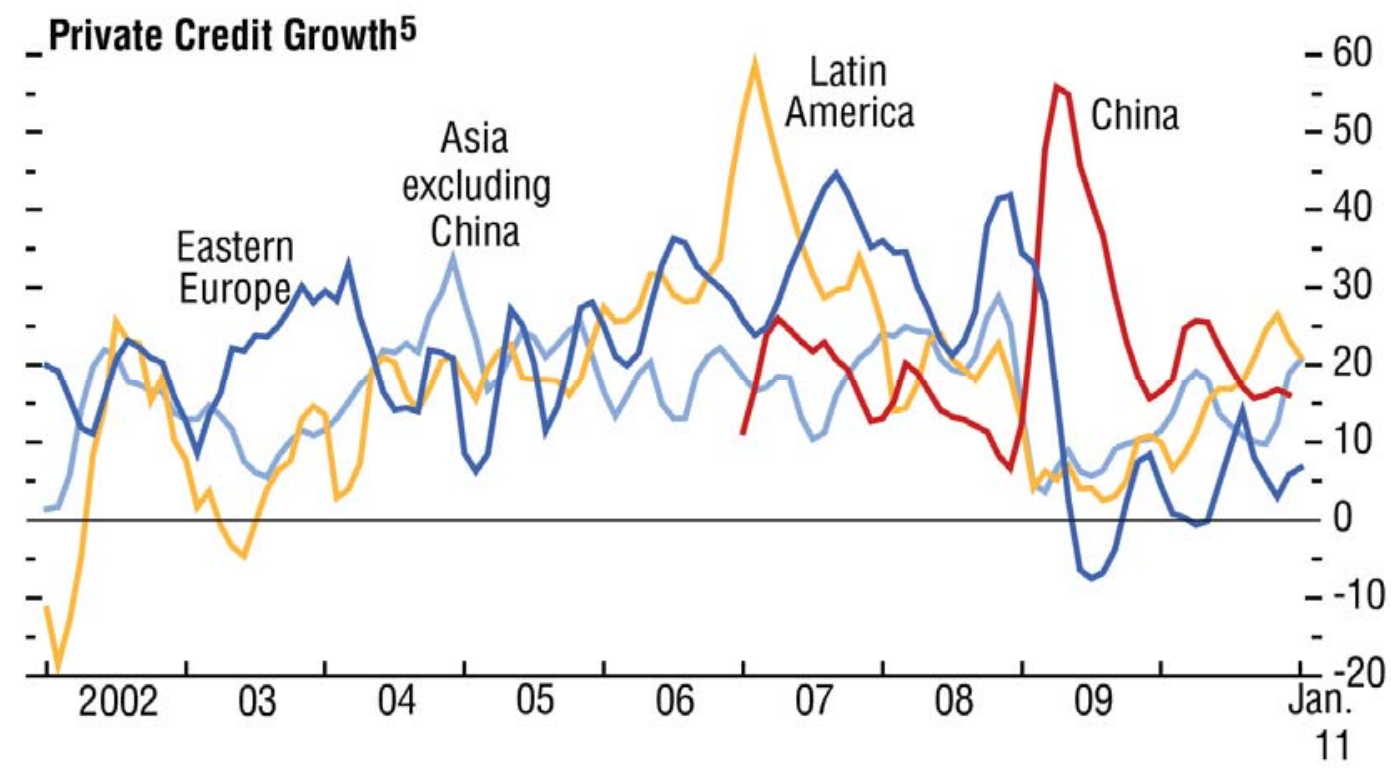

Source: International Monetary Fund, World Economic Outlook (April 2011).

Figure 5

Brazil, Colombia and Peru: Real Credit Growth to the Private sector, 2006-10

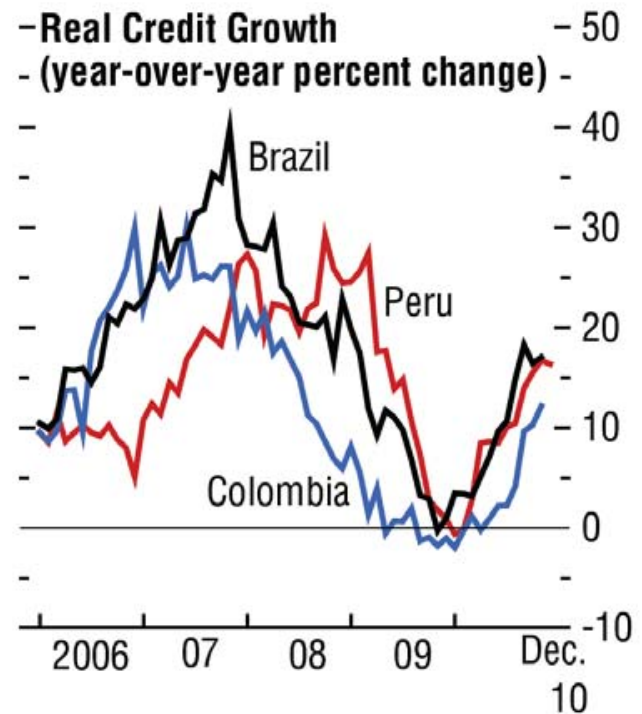

Source: International Monetary Fund, World Economic Outlook (April 2011). 
A fourth argument is that macroprudential policy is more subject to lobbying and political pressure than monetary policy. A case in point is the worldwide reaction of the financial sector to the proposed new Basel rules for higher capital requirements, even though research (for the United States and other countries) shows that this policy is likely to lead to only a modest increase in the cost of credit. $^{20}$

A fifth argument is that too much reliance on macroprudential policy, to the extent that it limits bank credit availability or lead to or higher borrowing costs, may foster financial disintermediation by promoting the development of shadow banking and the informal sector-making it in turn difficult to maintain financial stability. From that perspective, the scope and bluntness of the policy rate could be an advantage over macroprudential measures, because it is more difficult to circumvent a general increase in borrowing costs induced by a monetary policy contraction in the same way as regulations.

A sixth argument is that some of the "new" macroprudential tools envisaged in Basel III (as summarized in Table 1 ) are largely untested. ${ }^{21}$ There is no clear consensus yet on what tools will work and there is very little evidence on their effectiveness. For instance, regarding the performance of dynamic loan provisioning systems, much of the evidence relates to the Spanish case (see Saurina (2009)); yet, the conclusion from most studies is that even though these systems may succeed in making banks more resilient, they appear to have limited effectiveness when it comes to restraining credit growth. ${ }^{22}$ Similarly, the introduction of countercyclical capital buffers may create serious operational and institutional challenges, in countries where the supervisory environment (as is the case in many MICs) is weak to begin with. It is also not clear what variables they should be related to during the buildup and release phases. Interactions among macroprudential tools are also not well understood; a case

\footnotetext{
${ }^{20}$ See Admati et al. (2011) for the impact of capital requirements on the cost of equity and Igan and Mishra (2011) for a discussion of the connection between financial lobbying and financial legislation in the lead up to the US financial crisis. A more entertaining, albeit less academic account, is provided in C. Ferguson's documentary movie Inside Job.

${ }^{21}$ In particular, the long timeframe for their full implementation (5-6 years) reflects the cautious approach that the BCBS has taken, after many simulations of their micro and macro effects but without actual empirical evidence about how these new macroprudential instruments would affect credit and capital markets.

${ }^{22}$ As noted earlier, several countries in Latin America have introduced dynamic loan provisioning systems in recent years, but the experience is too recent to provide robust conclusions.
} 
in point is the interaction between bank capital requirements and dynamic loan provisioning systems. ${ }^{23}$ Finally, and quite importantly, some macroprudential tools may alter the way the monetary transmission mechanism operates (see the discussion below). What this all means is that there is a good case, if only for a transitory period (during which a better understanding of these issues can be acquired), to rely more on monetary policy to respond to financial stability concerns.

Table 1

Basel III: Phase-in Arrangements

(Shading indicates transition periods, all dates are as of 1 January)

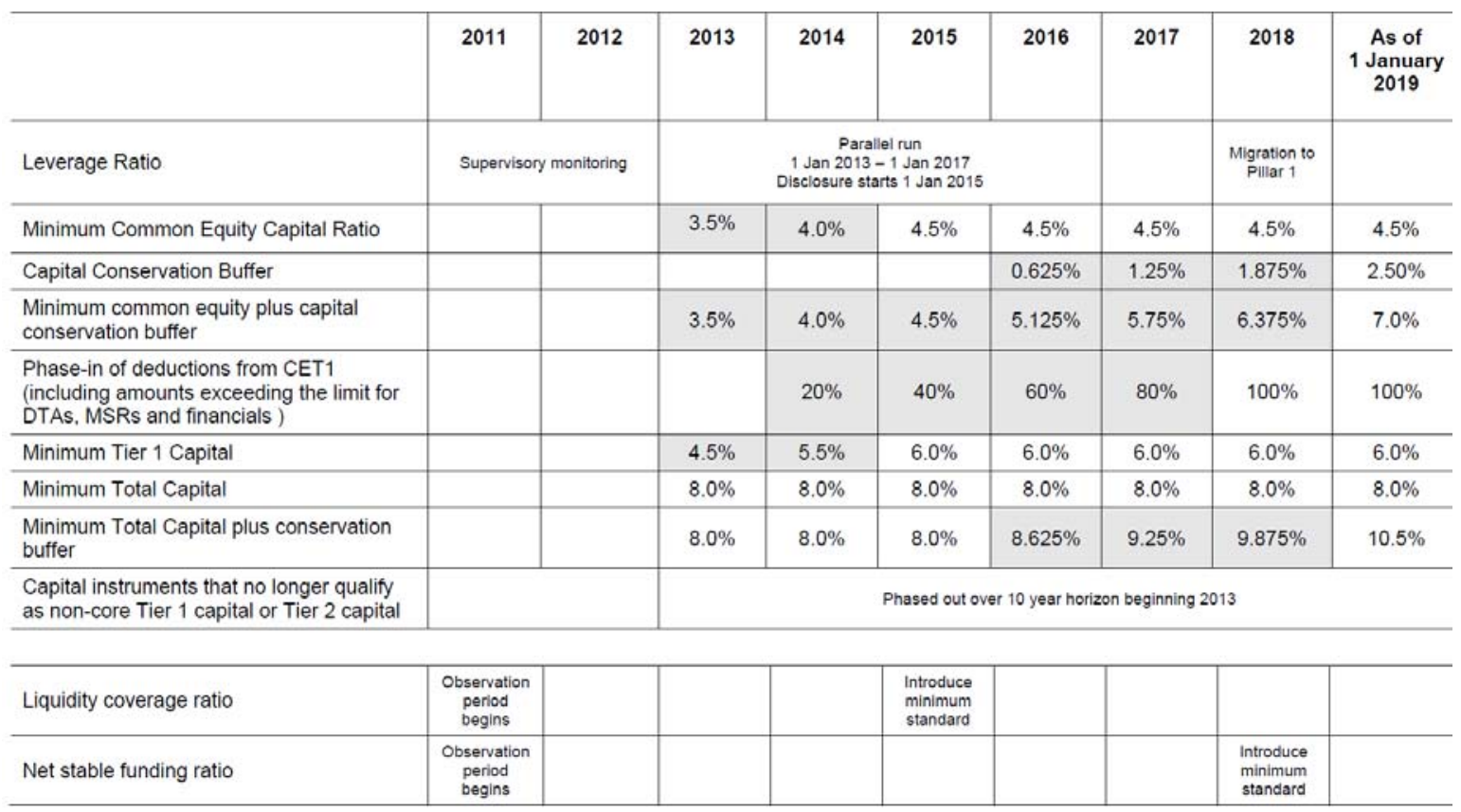

Source: Basel Committee on Banking Supervision (2010).

A seventh argument is that both macroeconomic instability and financial instability tend to increase in the lead-up to financial crises. ${ }^{24}$ This creates a case for monetary policy to react promptly, in normal times, to indications of growing financial vulnerability. By “leaning

\footnotetext{
${ }^{23}$ The common view is that bank capital should cover for unexpected credit losses, whereas dynamic loan loss provisions are intended to cover expected credit losses. However, introducing either one of those regulatory regimes while the other is present may change the behavior of banks and thus the effectiveness of both types of tools. This may occur, for instance, if the reasons why banks hold (excess) capital buffers are altered by the introduction of loan loss provisions, and if capital buffers have a signaling effect that translates into changes in their market borrowing costs.

${ }^{24}$ See Demirguc-Kunt and Detragiache (2005) for a review of the evidence for developing countries.
} 
against the financial cycle,” a more active monetary policy may help to stabilize conventional targets (output and inflation). In that case then there is a stabilization dividend. Indeed, a stable and sound financial system can contribute to macroeconomic stability by facilitating the transmission of monetary policy actions and cushioning the impact of macroeconomic shocks through the financial sector. In addition, a stable and sound financial system may decrease the incidence of financial stress and lead to less disruption to economic activity, which in turn contributes to price stability.

A final argument is that the view, according to which adding a financial stability objective may adversely affect central bank credibility, depends in fact on initial conditions. If, for instance, inflation is initially above target, a rise in the policy rate motivated by systemic risk concerns may actually be beneficial. What the "credibility problem" means is that there are new challenges for central banks in terms of transparency and communication of its policy decisions, and the indicators upon which they are based, but these are not insurmountable. After all, when some central banks in MICs initially adopted a measure of “core” inflation, as opposed to headline inflation, as their measure of price stability, they faced significant problems in conveying to the public the nature of their objective, and the reasons for making a particular choice; over time, with communication improving, these issues became better understood. There is no reason to believe that the same may not occur with a financial stability target — even though, as noted earlier, there is no consensus yet on how to measure financial stability. A good point of departure would therefore be to begin with a definition of financial stability as a final target. Because the concept has proved elusive, this is not a simple task; a sensible strategy perhaps is to follow an operational approach and respond to an intermediate financial target, as discussed in the next section.

\section{WHAT SHOULD MONETARY POLICY REACT TO?}

Assuming that the balance of arguments is in favor of a more proactive role for monetary policy — if only for a transitory period, as noted earlier —in addressing financial stability concerns, what should central banks react to? Many MICs have adopted a regime of 
flexible inflation targeting regime in recent years, with much success prior to the crisis. In these regimes, the optimal interest rate policy is a Taylor-type rule, which involves linking the policy interest rate to current or expected inflation and the output gap. ${ }^{25}$

Our view is that in the context of MICs, there is much merit in augmenting the interest rate rule by adding a measure of the private sector credit growth gap, defined as the difference between the actual growth rate of that variable and a "reference" growth rate. This would allow monetary policy (which can address only the time dimension of systemic risk, as noted earlier) to help to counter accelerator mechanisms that inflate credit growth and asset prices, which are common manifestations of financial imbalances. In particular, rapid credit growth tends to go hand-in-hand with a deterioration in lending origination standards and credit quality. During upturns, credit standards tend to be more lenient, both in terms of screening of borrowers and in collateral requirements. As a result, a greater number of riskier borrowers are able to secure bank loans, whereas the share of collateralized loans tends to decrease. During boom times, the adverse selection problems created by informational asymmetries between lenders and borrowers are therefore magnified. In turn, the weakening of lending standards may increase vulnerability to financial distress when the economy experiences a downturn. ${ }^{26}$

In addition, although credit and asset price cycles often exacerbate each other, several studies have found that credit is also a useful leading indicator of asset price busts; by contrast, there is no strong evidence that asset prices (in particular, equity prices) are good out-of-sample predictors. More generally, rapid credit growth— often associated with episodes of large capital inflows in MICs, as documented earlier—is often a warning sign of financial instability; even though not all episodes of credit booms end up in crises, almost invariably crises are preceded by episodes of credit booms. There is indeed robust evidence

\footnotetext{
${ }^{25}$ Such a feedback rule is optimal in that it derives from the first-order condition for the optimization of the central bank's objectives. See Svensson (1997) and Clark et al. (1999) for a formal analysis. Taylor rules, sometimes augmented with an exchange rate pressure variable, appear to perform fairly well in practice for some MICs; see for instance de Mello and Moccero (2011) for Latin America.

${ }^{26}$ See Dell'Ariccia and Marquez (2006) for a detailed discussion of the various channels through which lending booms may lead to a weakening of lending standards. Jiménez and Saurina (2006) provide evidence of a
} 
that credit booms raise significantly the likelihood of an asset price bust or a financial crisis in MICs. ${ }^{27}$ Recessions whose origin is the collapse of credit-fueled bubbles-periods during which banks make loans which appear to have abnormally low expected returns - also tend to be more severe and longer lasting than those generated by "normal” monetary policy contractions aimed at curbing inflationary pressures.

A third consideration is that, most MICs do not have reliable data on land and property prices; and equity prices tend to be highly volatile. By contrast, credit data are readily available and usually subject to only small revisions (if at all) over time. In practice, many central banks in MICs are already paying much attention to credit growth—without a doubt, because of the importance of banks in the financial system, as discussed earlier. ${ }^{28}$ The Central Bank of Turkey for instance monitors closely the change in credit in proportion to GDP, whereas the central bank of Morocco pays particularly attention to credit to the nonagricultural sector.

Another important argument for responding to a credit growth gap is that this could be desirable not only for macroprudential reasons, but also because of the unreliability of real time (preliminary) output gap measures in MICs. Figure 6 for instance shows output gap measures (with trend output estimated with a standard HP filter) based on real time and final real GDP estimates for Brazil. The figure shows clearly that the differences can be at times quite substantial, with errors going in both directions. Similar results are obtained for Turkey, as shown in Figure 6, and for Chile by Morandé and Tejada (2009). ${ }^{29}$ In the presence of large errors in the measurement of output gaps, it may in fact be optimal to reduce the weight

positive relationship between rapid credit growth and loan losses in Spain. The evidence for MICs is more limited but goes in the same direction. See the FSB Working Group on Credit Origination (2010).

${ }^{27}$ See International Monetary Fund (2009), Claessens et al. (2010) and Calderón and Fuentes (2011). Gerdesmeier et al. (2010) found that credit aggregates also play a significant role in predicting asset price busts in industrial countries. However, Assenmacher-Wesche and Gerlach (2010) found that for these countries deviations of credit and asset prices from trend (viewed as measures of financial imbalances) contain little useful information for forecasting future economic conditions. This is consistent with the view that the link between credit growth and financial instability is weaker in countries with deep financial markets.

${ }^{28}$ Many respondents to a survey conducted by BCBS in 2010 cited credit growth or credit-to-GDP measures as leading indicators of the cycle.

${ }^{29}$ Studies for industrial countries, such as Olsen et al. (2002) and Marcellino and Musso (2011) also find differences in the behavior of revised and unrevised output gaps that can be quite significant for advanced economies as well-although, as argued in the latter study, they are not necessarily due to data revisions. 
attached to the output gap in a "real time" Taylor-type policy rule. At the same time, if the credit growth gap is closely related to final estimated output, the weight of that variable should be increased. ${ }^{30}$

Figure 6

Brazil: Real time and Final HP-based Output Gaps, 1996-2008

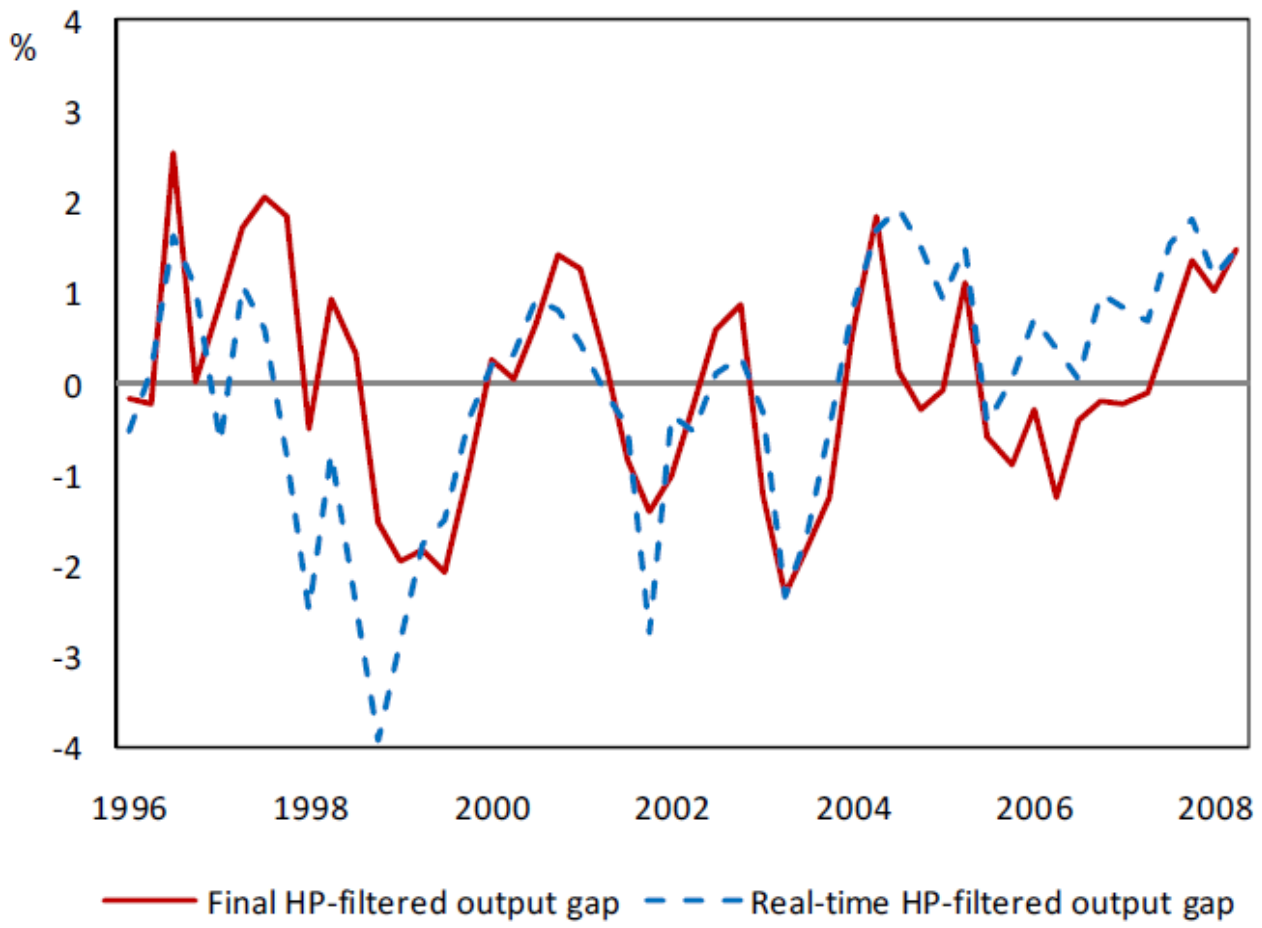

Source: Cusinato et al. (2009).

In a sense, the credit growth gap can be viewed as an intermediate target, concerns about which are easier to convey than those about a multi-faceted and hard-to-define final target, financial stability. In this approach, there is therefore an asymmetry in defining the central bank's policy loss function, because inflation and output are final targets. Because of the difficulty of defining financial stability as a final target (at least in the current state of

\footnotetext{
${ }^{30} \mathrm{~A}$ similar argument was recently proposed by Scharnagl et al. (2010), with respect to money growth in the Euro area. Using numerical analysis, they found that the greater the degree of output gap uncertainty, the greater the benefits of incorporating a money growth response are in terms of reducing volatility in output, inflation and interest rates. They argue that the main reason for this is that real-time data on money growth contain valuable information on the true level of current output growth, which is not otherwise known to policymakers in real time with a sufficient degree of precision.
} 
affairs), using an intermediate target that is easier to define may facilitate communication with the public and alleviate, to some extent, the credibility issues mentioned earlier.

Figure 7

Turkey: Real time and Final HP-based Output Gaps, 2005-08

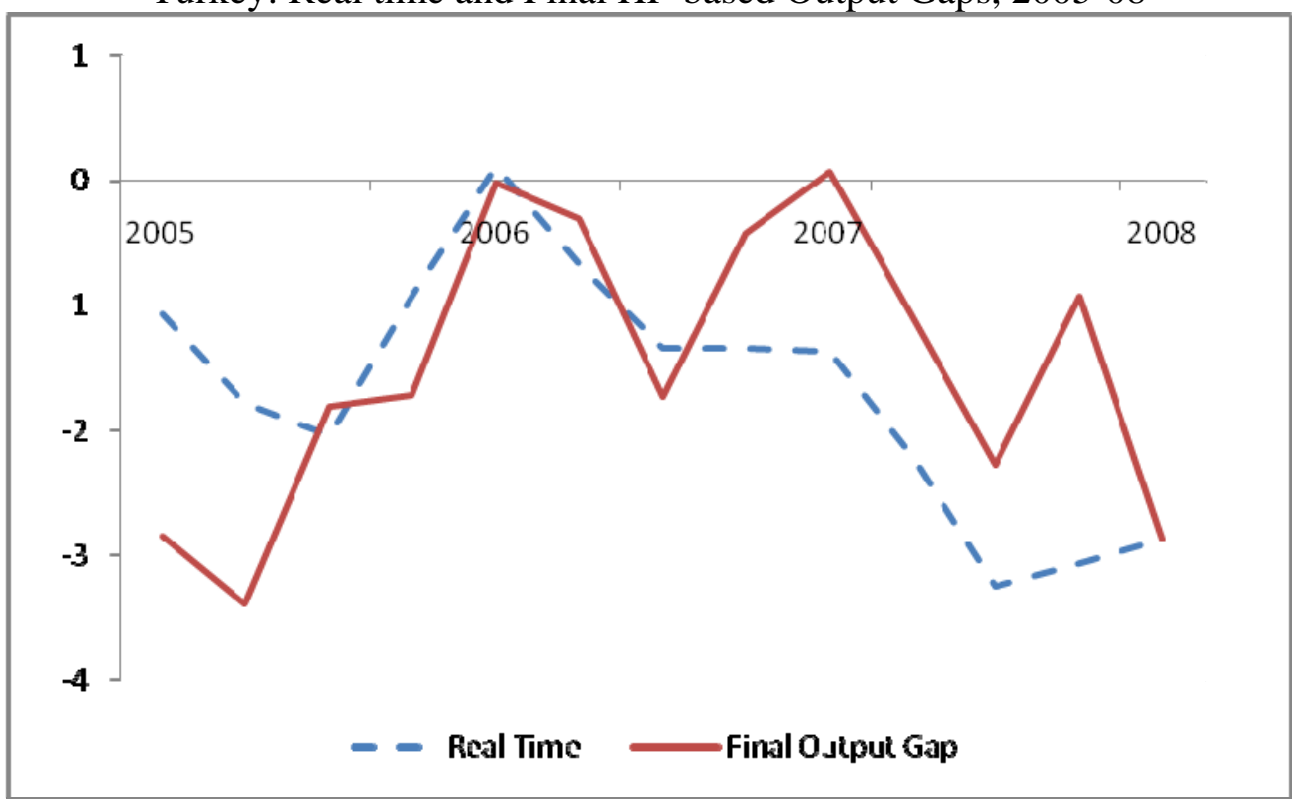

Source: Central Bank of Turkey.

The practical implementation of this "augmented" policy rule needs of course to be thought out carefully. A first issue is whether the central bank should consider a real or a nominal credit gap, and whether it should consider a broad measure of aggregate credit or only a component of total credit. As noted earlier, working capital loans are related to changes in the supply side, not the demand side, of the economy; if the credit growth gap is to be used in part as a substitute to the output gap as a measure of excess aggregate demand, it might be argued that these should be excluded from the measure to which the central bank should respond to. However, it may also be argued that working capital loans are substitutes for firms' internal resources (or cash flows), which can now be used to finance longer-term investment — which indirectly has an impact on aggregate demand; this would militate in favor of using a broad aggregate. Fungibility and evergreening problems are also important considerations in choosing between narrow and broad credit aggregates. 
A second issue is whether the "reference" growth rate should be calculated as a trend (as proposed for instance in the calculation of the countercyclical capital buffer under Basel III) or rather on the basis of an equilibrium credit-to-GDP ratio that is related to some fundamental determinants, such as population growth, urbanization, and so on. This second approach may be more appropriate for MICs, because it would help to account for financial inclusion - an important consideration for many countries where the scope of the formal financial system, and access to credit and other financial services, are limited to begin with. The implicit view here is that financial inclusion, by reducing reliance on the unregulated financial system, and increasing opportunities for risk sharing and consumption smoothing, helps to promote financial stability in the longer run (see Hawkins (2006)).

At the same time, it is important to keep in mind that the credit growth gap is still a noisy indicator; false signals are inevitable and may raise the risk of policy errors. A policy response should be contingent on the magnitude of the credit growth gap. In so doing, the primacy of the macroeconomic stability objective in "normal times" would be maintained and credibility problems would be mitigated. At the same time, during episodes of sudden floods induced by external shocks, raising policy interest rates by more to account for excessive credit growth may exacerbate the problem by triggering more inflows, as discussed earlier. Both points are arguments for combining an (augmented) monetary policy rule with macroprudential tools. Indeed, given that monetary policy cannot address the cross-section dimension of systemic risk (that is, how risk is distributed within the financial system at a point in time), a combination of these two policies is inescapable.

\section{HOW SHOULD MACROPRUDENTIAL REGULATION AND MONETARY POLICY BE COMBINED?}

An important practical issue for central banks is how an augmented monetary policy rule and macroprudential rules should be combined. An important part of the answer requires understanding how the two policies interact. As noted earlier, even though Tinbergen's principle implies that in a deterministic world the two policies are complements if the two 
objectives (macroeconomic stability, financial stability) are to be achieved exactly, they may be substitutes if the central bank's goal (in a stochastic environment) is to minimize deviations from targets over time, rather than achieve them exactly and continuously. This would occur if each instrument affects both targets in the same direction (lower volatility); due to decreasing marginal returns to each instrument, they may reinforce each other. It is therefore important to study jointly augmented monetary policy rules and macroprudential rules to understand how they should be combined.

Studies along these lines for MICs include those of Agénor, Alper, and Pereira da Silva (2011a, 2011b), which focus on a Basel III-type countercyclical regulatory rule and a monetary policy rule augmented with a credit growth gap (measured in terms of deviations of the growth rate of credit for investment from its steady-state value). Thus, the central bank sets its policy instrument in part to "lean against the wind" in a systematic fashion. Capital adequacy requirements are decomposed into a deterministic (minimum) requirement and a cyclical component related again to deviations of the growth rate of credit for investment from its steady-state value. Macroeconomic stability is defined initially in terms of the volatility of nominal income (thereby imposing implicitly equal weights on output and price volatility), whereas financial stability is defined in terms of the volatility of real house prices. ${ }^{31}$ A composite index of economic stability is also defined, with two sets of weights: first with equal weights of 0.5 to each objective of stability, and second with a weight of 0.8 for macroeconomic stability and 0.2 for financial stability. Thus, the first case assumes that the central bank is equally concerned with macroeconomic and financial stability, whereas the second assumes that it attaches more importance to macroeconomic stability.

In response to a positive housing demand shock (meant to capture a housing boom) or a sudden flood (large capital inflows induced by external shocks), the analysis shows that the two instruments are complementary rather than substitutes; even with aggressive response to inflation and credit growth gaps, it is optimal to rely also on the countercyclical regulatory rule under certain circumstances. This complementarity is particularly important during

\footnotetext{
${ }^{31}$ Other proxies are also considered in those papers.
} 
episodes of sudden floods where, as indicated earlier, the ability of the central bank to respond to inflationary pressures by raising interest rates.

\section{ARE MODELS FOR MONETARY POLICY ANALYSIS UP TO THE TASK?}

The foregoing discussion suggests that if multiple instruments are going to be used to achieve macroeconomic and financial stability in MICs, their interaction needs to be clearly understood; to do so requires using policy models that are appropriate for the economic environment of these countries. As noted earlier, financial market imperfections remain pervasive in most MICs and cover a broad spectrum. The importance of banks and bank credit means that models must account for their macroeconomic role in the transmission of policy and exogenous shocks. In particular, because banks continue to play a dominant role in the financial system in MICs, the use of macroeconomic models that account for credit market imperfections is essential to study the effectiveness of monetary and macroprudential policies and how these policies interact.

From that perspective, a review of the current analytical literature provides mixed lessons. The simple New Keynesian model, which has been promoted and used as a "workhorse" for monetary policy analysis in industrial countries (applied at times with little critical judgment to MICs) is by now largely discredited. The emerging new consensus is that the performance of monetary policy and macroprudential rules should be studied in macroeconomic models that provide indeed a better account of the financial sector and its imperfections. Several new models for industrial countries have focused on financial systems in which marginal suppliers of credit are no longer commercial banks, and deposits no longer the most important marginal source of funding. However, there has been limited progress in developing models for MICs that focus on bank-dominated systems. ${ }^{32}$

\footnotetext{
${ }^{32}$ For a discussion of the New Keynesian model, see Galí and Gertler (2007). Woodford ((2010) reviews some of the recent macroeconomic models with financial frictions that have recently been developed for industrial countries. He concludes in favor of using credit spreads as an additional determinant of the policy rate in the Taylor rule. However, the evidence suggests that broader credit channel variables, in the Bernanke-Gertler financial accelerator approach, seem to matter more empirically, at least for the United States; see for instance Yagihashi (2011).
} 
One recent contribution along these lines is Agénor and Pereira da Silva (2011), who present a simple dynamic model that captures some of the key credit market imperfections commonly found in MICs. Even though its aggregate demand relationships are not derived from first principles, they are fairly intuitive and consistent with the evidence. ${ }^{33}$ The model is used to analyze the interactions between monetary and macroprudential policies, involving, in the latter case, changes in reserve requirements and the imposition of an upper limit on banks' leverage ratio. ${ }^{34} \mathrm{~A}$ broad lesson of the analysis—-which may be equally relevant for industrial countries - is that understanding how these tools operate is essential because they may alter, possibly in substantial ways, the monetary transmission mechanism. Continuing this line of research is an essential task for MICs — and, indeed, for advanced economies — to study interactions between monetary policy and macroprudential regulation, and quantify the impact of policy rates on asset prices, credit growth, and other measures of financial imbalances.

\section{CONCLUDING REMARKS}

A key issue on the agenda of policymakers, in industrial and middle-income developing countries alike, relates to the roles of monetary policy and macroprudential rules in mitigating procyclicality and promoting macroeconomic and financial stability. In this paper, we focused the discussion on the arguments, for and against attributing an explicit financial stability objective to monetary policy—as a complement, or substitute, to macroprudential policy. This discussion was conducted from the perspective of middle-income countries, where banks continue to dominate the financial system and bank credit plays a critical role both on the supply and demand sides. We also discussed, assuming that a more proactive role is desirable, what monetary policy should react to, to what extent it should be combined with macro-prudential regulation (and possibly capital controls), and to what extent

\footnotetext{
${ }^{33}$ As a result, the model is vulnerable to the Lucas critique. However, replacing these empirically-based behavioral relationships by optimization-based first-order conditions for which knowledge is incomplete or limited does not eliminate the problem. See Caballero (2010) for a more detailed discussion.

${ }^{34}$ Reserve requirements are increasingly used for financial stability purposes, and could be seen as macroprudential to the extent that they limit liquidity risk. As shown in Table 1, a leverage ratio is also being considered as part of Basel III.
} 
existing models for monetary policy analysis are up to the task, when it comes to studying how these policies interact and quantifying their impact on the economy.

The findings in this paper bear on the broader debate, sparked by the global financial crisis, about the role of monetary policy and macroprudential regulation—viewed independently and jointly_in achieving macroeconomic and financial stability in both industrial and developing countries. Our review of the various arguments that have been put forward indicates that, on balance, there may be a good case for monetary policy in MICs to be more proactive and address the time dimension of systemic risk-if only during a transitory period, as more is learnt about the implementation and performance of the new macroprudential rules that are currently being discussed, as part of the Basel III agreement and in other policy circles. In particular, there are robust arguments in favor of monetary policy in MICs reacting to a measure of (private sector) credit growth gap because of concerns about financial stability. The credit growth gap acts as an intermediate target, which is relatively easy to calculate (given a reference growth rate) and easier to explain to the public than the more elusive final target financial stability. By making the policy response contingent on the magnitude of the credit growth gap itself, the primacy of the macroeconomic stability target in "normal” times would be maintained and credibility problems mitigated. Another important argument for responding to the credit growth gap is the high degree of uncertainty in these countries about real time estimates of the output gap. In that sense, the credit growth gap may act also as a more reliable proxy for excess aggregate demand. In fact, there is evidence that central banks in MICs have long paid particular attention to credit growth indicators for that reason. In that sense, our proposed rule is not simply normative in nature.

Nevertheless, our analysis also implies that there is no escape from the fact that monetary policy in MICs needs to be combined with macroprudential regulation-because monetary policy cannot, in any event, address the cross-section dimension of systemic risk, and because these countries often face circumstances (such as sudden floods in capital flows) where interest rate policy may have undesirable side effects that may be detrimental to macroeconomic and financial stability. 


\section{References}

Admati, Anat R., Peter M. DeMarzo, Martin F. Hellwig, and Paul Pfeiderer, "Fallacies, Irrelevant Facts, and Myths in the Discussion of Capital Regulation: Why Bank Equity is Not Expensive,” unpublished, Stanford University (2011).

Agénor, Pierre-Richard, “Business Cycles, Economic Crises, and the Poor: Testing for Asymmetric Effects,” Journal of Policy Reform, 5 (October 2002), 145-60.

—_, "International Financial Integration: Benefits, Costs, and Policy Challenges," in Survey of International Finance, ed. by H. Kent Baker and Leigh A. Riddick, eds., Oxford University Press (Oxford: 2011).

Agénor, Pierre-Richard, Koray Alper, and Luiz Pereira da Silva, "Capital Requirements and Business Cycles with Credit Market Imperfections,” Policy Research Working Paper No. 5151, World Bank (December 2009). Forthcoming, Journal of Macroeconomics.

—_, "Capital Regulation, Monetary Policy and Financial Stability,” Working Paper No. 154, Centre for Growth and Business Cycles Research (March 2011a).

—, "Sudden Floods, Macroprudential Regulation and Stability in an Open Economy,” unpublished, University of Manchester, Central Bank of Brazil, and Central Bank of Turkey (July 2011b).

Agénor, Pierre-Richard, and Luiz Pereira da Silva, "Cyclical Effects of Bank Capital Requirements with Imperfect Credit Markets,” Policy Research Working Paper No. 5067, World Bank (September 2009). Forthcoming, Journal of Financial Stability.

—, "Reforming International Standards for Bank Capital Requirements: A Perspective from the Developing World," in International Banking in the New Era: PostCrisis Challenges and Opportunities, ed. by S. Kim and M. D. McKenzie, IFR Vol. No 11, Emerald (Bingley: 2010).

—, "Macroprudential Regulation and the Monetary Transmission Mechanism," unpublished, University of Manchester and Central Bank of Brazil (July 2011).

Ahrend, Rudiger, "Monetary Ease: A Factor behind Financial Crises? Some Evidence from OECD Countries,” Economics, 4, No. 2010-12 (April 2010).

Ariyoshi, Akira, and others, Capital Controls: Country Experiences with their Use and Liberalization, Occasional Paper No. 190, International Monetary Fund (Washington DC: 2000).

Assenmacher-Wesche, Katrin, and Stefan Gerlach, "Monetary Policy and Financial Imbalances: Facts and Fiction,” Economic Policy, 25 (July 2010), 437-82. 
Basel Committee on Banking Supervision, "Basel III: A Global Regulatory Framework for more Resilient Banks and Banking Systems,” Report No. 189 (December 2010).

Bernanke, Ben S., "Monetary Policy and the Housing Bubble," speech to the American Economic Association, Atlanta, Georgia (January 2010).

Blinder, Alan S., "How Central should the Central Bank Be?,” Journal of Economic Perspectives, 48 (March 2010), 123-33.

Broto, Carmen, Javier Díaz-Cassou, and Aitor Erce, "Measuring and Explaining the Volatility of Capital Flows to Emerging Countries,” Journal of Banking and Finance, 35 (August 2011), 1941-53.

Brunnermeier, Markus, Andrew Crockett, Charles Goodhart, Avinash D. Persaud, and Hyun Shin, The Fundamental Principles of Financial Regulation, International Center for Monetary and Banking Studies (Geneva: 2009).

Caballero, Ricardo J., "Macroeconomics after the Crisis: Time to Deal with the Pretense-of-Knowledge Syndrome," Journal of Economic Perspectives, 24 (September 2010), 85-102.

Calderón, Cesar, and J. Rodrigo Fuentes, "Characterizing the Business Cycles of Emerging Economies,” unpublished, World Bank (January 2011).

Committee on the Global Financial System, "Macroprudential Instruments and Frameworks: A Stocktaking of Issues and Experiences,” CGFS Paper No. 38, Bank for International Settlements (May 2010).

Claessens, Stijn, M. Ayhan Kose, and Marco E. Terrones, "How do Business and Financial Cycles Interact?,” Working Paper No. 11/88, International Monetary Fund (April 2011).

Clark, Peter B., Charles A. E. Goodhart, and Haizhou Huang, “Optimal Monetary Policy Rules in a Rational Expectations Model of the Phillips Curve,” Journal of Monetary Economics, 43 (April 1999), 497-520.

Committee on the Global Financial System, "Capital Flows and Emerging Market Economies,” CGFS Working Paper No. 33, Bank for International Settlements (January 2009).

Crowe, Christopher, Giovanni Dell’Ariccia, Deniz Igan, and Pau Rabanal, “Policies for Macrofinancial stability: Options to Deal with Real Estate Booms,” Staff Discussion Note No. 11/02, International Monetary Fund (February 2011). 
Cusinato, Rafael T., André Minella, and Sabino da Silva Porto Jr., “Output Gap and GDP in Brazil: A Real-Time Data Analysis,” Working Paper No. 203, Central Bank of Brazil (April 2010).

Dell' Ariccia, Giovanni and Robert Marquez, "Lending Booms and Lending Standards,” Journal of Finance, 61(October 2006), 2511-46.

de Mello, Luiz, and Diego Moccero, "Monetary Policy and Macroeconomic Stability in Latin America: The Cases of Brazil, Chile, Colombia and Mexico," Journal of International Money and Finance, 30 (February 2011), 229-45.

Demirguc-Kunt, Asli, and Enrica Detragiache, "Cross-Country Empirical Studies of Systemic Bank Distress: A Survey,” National Institute Economic Review, 192 (April 2005), 68-83.

Dufrénot, Gilles, Valérie Mignon, and Anne Péguin-Feissolle, “The Effects of the Subprime Crisis on the Latin American Financial Markets: An Empirical Assessment,” Economic Modelling, 28 (September 2011), 2342-57.

Financial Stability Board, "Macroprudential Policy Tools and Frameworks: Update for G20 Finance Ministers and Central Bank Governors,” unpublished (February 2011).

Fonseca, Ana R., Francisco González, and Luiz Pereira da Silva, "Cyclical Effects of Bank Capital Buffers with Imperfect Credit Markets: International Evidence,” Working Paper No. 216, Central Bank of Brazil (October 2010).

Forbes, Kristin J. and Francis E. Warnock, "Capital Flow Waves: Surges, Stops, Flight and Retrenchment,” unpublished, University of Virginia (May 2011).

Furceri, Davide, Stephanie Guichard, and Elena Rusticelli, “The Effect of Episodes of Large Capital Inflows on Domestic Credit,” Working Paper No. 864 OECD Economics Department (May 2011).

Galati, Gabriele, and Richhild Moessner, "Macroprudential Policy-A Literature Review,” Working Paper No. 337, Bank for International Settlements (February 2011).

Galí, Jordi, and Mark Gertler, "Macroeconomic Modeling for Monetary Policy Evaluation,” Journal of Economic Perspectives, 21 (September 2007), 25-45.

Gerdesmeier, Dieter, Hans-Eggert Reimers, and Barbara Roffia, “Asset Price Misalignments and the Role of Money and Credit,” International Finance, 13 (December 2010), 377-407.

Gochoco-Bautista, Maria S., Juthathip Jongwanich, and Jong-Wha Lee, "How Effective are Capital Controls in Asia?,” Working Paper No. 224, Asian Development Bank (October 2010). 
Habermeier, Karl, Annamaria Kokenyne, and Chikako Baba, "The Effectiveness of Capital Controls and Prudential Policies in Managing Large Inflows," Staff Discussion Note No. SDN/11/14, International Monetary Fund (August 2011).

Hawkins, Penelope, "Financial Access and Financial Stability," in Central Banks and the Challenge of Development, Bank for International Settlements (Basel: 2006).

Hendricks, Darryll, John Kambhu, and Patricia Mosser, "Systemic Risk and the Financial System,” Appendix in New Directions for Understanding Systemic Risk, Proceedings of a Conference Cosponsored by the Federal Reserve Bank of New York and the National Academy of Sciences (New York, NY: 2007).

Herrmann, Sabine, and Dubravko Mihaljek, "The Determinants of Cross-Border Bank Flows to Emerging Markets: New Empirical Evidence on the Spread of Financial Crises,” Working Paper No. 315, Bank for International Settlements (July 2010).

Igan, Deniz, and Prachi Mishra, “Making Friends," Finance and Development, 48 (June 2011), 27-29.

International Monetary Fund, "Lessons for Monetary Policy from Asset Price Fluctuations,” Chapter 3 in World Economic Outlook October 2009, International Monetary Fund (Washington DC: 2009).

—, "Recent Experiences in Managing Capital Inflows-Cross-Cutting Themes and Possible Policy Framework," unpublished, Strategy, Policy and Review Department (February 2011a).

__, "Macroprudential Policy: An Organizing Framework," unpublished, Monetary and Capital Markets Department (March 2011b).

Jongwanich, Juthathip, "Capital Flows and Real Exchange Rates in Emerging Asian Countries,” Working Paper No. 210, Asian Development Bank (July 2010).

Jongwanich, Juthathip, Maria S. Gochoco-Bautista, and Jong-Wha Lee, "When are Capital Controls Effective? Evidence from Malaysia and Thailand,” Working Paper No. 251, Asian Development Bank (March 2011).

Marcellino, Massimiliano, and Alberto Musso, “The Reliability of Real-time Estimates of the Euro Area Output Gap,” Economic Modelling, 28 (July 2011), 1842-56.

McCauley, Robert N., "Managing Recent Hot Money Inflows in Asia,” Discussion Paper No. 99, Asian Development Bank Institute (March 2008).

Mishkin, Frederic S., “Monetary Policy Strategy: Lessons from the Crisis,” Working Paper No. 16755, National Bureau of Economic Research (February 2011). 
Montoro, Carlos, and Ramon Moreno, "The Use of Reserve Requirements as a Policy Instrument in Latin America," Quarterly Review, Bank for International Settlements (March 2011), 53-65.

Morandé, Felipe, and Mauicio Tejada, "Sources of Uncertainty in Conducting Monetary Policy in Chile,” in Monetary Policy under Uncertainty and Learning, ed. by Klaus Schmidt-Hebbel and Carl E. Walsh, Central Bank of Chile (Santiago: 2009).

Moreno, Ramon, “Policymaking from a 'Macroprudential' Perspective in Emerging Market Economies,” Working Paper No. 336, Bank for International Settlements (January 2011).

Park, Cyn-Young, and Jong-Wha Lee, "Financial Integration in Emerging Asia: Challenges and Prospects,” Working Paper No. 79, Asian Development Bank (May 2011).

Pozsar, Zoltan, Tobias Adrian, Adam Ashcraft, and Hayley Boesky, "Shadow Banking,” Staff Report No. 458, Federal Reserve Bank of New York (July 2010).

Rajan, Raghuram G., "Has Financial Development Made the World Riskier?,” in The Greenspan Era: Lessons for the Future, Federal Reserve Bank of Kansas (Kansas City: 2005).

Saurina, Jesús, “Dynamic Provisioning: The Experience of Spain,” Crisis Response Note No. 7, International Finance Corporation (July 2009).

Jiménez, Gabriel, and Jesús Saurina, "Credit Cycles, Credit Risk, and Prudential Regulation,” International Journal of Central Banking, 2 (June 2006), 65-98.

Schou-Zibell, Lotte, Jose R. Albert, and Lei L. Song, “A Macroprudential Framework for Monitoring and Examining Financial Soundness,” Working Paper No. 43, Asian Development Bank (March 2010).

Scharnagl, Michael, Christina Gerberding, and Franz Seitz, "Should Monetary Policy Respond to Money Growth? New Results for the Euro Area,” International Finance, 13 (December 2010), 409- 41.

Svensson, Lars E. O., "Inflation Forecast Targeting: Implementing and Monitoring Inflation Targets,” European Economic Review, 41 (June 1997), 1111-46.

—, "Inflation Targeting and Financial Stability,” keynote lecture at the CEPR/ESI 14th Annual Conference, hosted by the Central Bank of Turkey (October 2010).

Terrier, Gilbert, Rodrigo Valdés, Camilo E. Tovar, Jorge Chan-Lau, Carlos Fernández-Valdovinos, Mercedes García-Escribano, Carlos Medeiros, Man-Keung Tang, 
Merced Vera Martin, and Chris Walker, "Policy Instruments to Lean against the Wind in Latin America,” Working Paper No. 11/159, International Monetary Fund (July 2011).

Wadhwani, Sushil, "Should Monetary Policy Respond to Asset Price Bubbles? Revisiting the Debate,” National Institute Economic Review, 206 (March 2008), 25-34.

Wezel, Torsten, "Dynamic Loan Provisions in Uruguay: Properties, Shocks, Absorption Capacity and Simulations using Alternative Formulas,” Working Paper No. 10/125, International Monetary Fund (May 2010).

Woodford, Michael, "Financial Intermediation and Macroeconomic Analysis," Journal of Economic Perspectives, 24 (September 2010), 21-44.

Yagihashi, Takeshi, "Estimating Taylor Rules in a Credit Channel Environment," forthcoming, North American Journal of Economics and Finance (December 2011). 


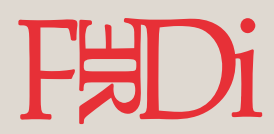

Créée en 2003, la Fondation pour les études et recherches sur le développement international vise à favoriser la compréhension du développement économique international et des politiques qui l'influencent.

\section{$\rightarrow$ Contact}

www.ferdi.fr

contact@ferdi.fr

+33(0)473177530 